$\beta$-D- $N$-acetylglucosaminidase

amniocentesis arylsulfatase A enzyme activity fetus fibroblast $\beta$-galactosidase genetic disease metabolic aberrations

\title{
Intrauterine Diagnosis: Comparative Enzymology of Cells Cultivated from Maternal Skin, Fetal Skin, and Amniotic Fluid Cells
}

\author{
Mrchael M. Kaback ${ }^{[31]}$, Clatre O. Leonard, and Tim H. Parmley \\ Departments of Pediatrics and Obstetrics-Gynecology, Johns Hopkins University School of Medicine, \\ and the Harriet Lane Service, Johns Hopkins Children's Medical and Surgical Center, \\ Baltimore, Maryland, USA
}

\begin{abstract}
Extract
The specific activities of three disease-related lysosomal enzymes were compared in cultured skin fibroblasts from seven normal women (M), their fetuses (F), and cells cultured from corresponding amniotic fluid cells (A). All samples were obtained in weeks 17-21 of pregnancy. Highly significant differences in the mean specific activities of $\beta$-galactosidase $(\beta$-Gal), $\beta$-D- $N$-acetylglucosaminidase (Hex), and arylsulfatase A (ARA) are evident in control cells developed from each of these sources. In addition, the pattern of differences in the three cell types was dissimilar for each enzyme. The mean activities in nanomoles of product produced per hour per milligram of soluble cell protein were: $\beta$-Gal: $\mathrm{F}=248, \mathrm{~A}=676, \mathrm{M}=375$; Hex: $\mathrm{F}=3412$, $\mathrm{A}=6548$, $\mathrm{M}=6781$; and $\mathrm{ARA}: \mathrm{F}=143, \mathrm{~A}=244, \mathrm{M}=458$. The differences in enzyme specific activities between the three cell types studied indicated significant differences in the enzymology of these cells under defined culture conditions. In light of these findings the prerequisites necessary for antenatal diagnosis of inherited metabolic disorders are recommended.
\end{abstract}

\section{Speculation}

If quantitative enzymologic data from cultured amniotic fluid cells are to be used for the antenatal diagnosis of specific inherited genetic disorders, it is essential that relative specific activities of the enzymes in question be established in cultured cells from each of the pertinent cell types. This is essential if heterozygous fetuses are to be correctly identified in utero and if fetal tissues are to be used to corroborate intrauterine diagnoses based on amniotic cell analysis.

\section{Introduction}

The use of cultivated somatic cells in the diagnosis of numerous cytogenetic, enzymatic, and metabolic diseases in man is well established [9]. It is now apparent that somatic fetal cells (amniotic fluid cells obtained by amniocentesis) may serve the same purpose $[4,14]$.
Certainly there is little question that amniotic fluid cells can be used for accurate delineation of fetal sex and chromosomal complement [15, 19, 22].

The use of amniotic fluid cell cultures, however, for the diagnosis of enzymatic-metabolic disorders in the fetus raises some clearly different issues. Unlike cytoge- 
netic analysis or sex determination, where interpretations are generally incontrovertible, biochemical or enzymatic parameters of somatic cells in culture may be subject to many biologic, genetic, or in vitro culture variables which could, in turn, critically affect interpretation. Quantitative ranges of enzyme specific activity may vary considerably in vitro in cells from both control and affected individuals. The exact explanation for this variation is not completely understood but may depend on such things as the particular assay used, the media and serum in which the cultures are grown $[5,13]$, the length of time cells have been in culture [3], the degree of confluency of cells at harvest $[8,10]$, and so on.

Since quantitative ranges of metabolic activity may be affected by these variables, this is particularly critical if differentiation of the heterozygous from the affected fetus is to be achieved on the basis of analysis of cultured amniotic fluid cells. Clearly this applies only to the autosomal recessive disorders since carriers of cytogenetic disorders can usually be readily identified and for the X-linked diseases a female fetus, at risk of being a carrier, would not be aborted in any case.

The ability to distinguish between the heterozygous and the affected fetus on the basis of cultured amniotic fluid cell analysis must be considered before any genetic-metabolic disease is approached in utero. Inability to achieve this differentiation could result in a $75 \%$ chance of abortion being recommended for each pregnancy. It is readily calculated that, for a family in such a situation, there is a $24 \%$ risk that five successive pregnancies would be terminated. The psychological trauma of such an experience to a couple, anxious and hopeful of having their own children, would probably be disastrous.

In addition to this potential problem of in utero carrier detection, there are several other considerations raised by the use of cultured amniotic fluid cells for the antenatal detection of metabolic disorders. For example, one cannot assume because of morphologic similarities that fibroblastic cells from different sources will be identical biochemically. Extrapolation of biochemical data from postnatal skin fibroblasts to cultured amniotic fluid cells need not be reliable. Do biochemical variables in amniotic fluid cells exactly reflect fetal characteristics? This is another question of primary importance and necessitates the definition of enzyme specific activities in tissues obtained from normal fetuses at the appropriate stage of gestation. Certainly, before these questions can be answered in the test situation, the normal relations of enzyme specific activities between each of the pertinent cell types must be established in control material.

With these considerations in mind, we have conducted a series of experiments to compare the specific activities of three disease-related enzymes in control fibroblast cultures derived from maternal skin, fetal skin, and corresponding amniotic fluid cells [7]. The design of these experiments was to mimic as closely as possible the conditions under which intrauterine diagnosis would be conducted and to achieve as much internal control of genetic variables as possible. Accordingly, seven women, between weeks 17 and 21 of pregnancy, undergoing either hysterotomy or total abdominal hysterectomy as a therapeutic abortive procedure, were studied. In all cases, the indication for termination of pregnancy was "psychosocial," and no significant history of pertinent medical-neurologic disease was present in the women or their families.

The enzymes reported in these studies are three acid hydrolases, presumably of lysosomal origin, which are specifically associated with three autosomal recessive, severe, untreatable, neurodegenerative disorders: $\beta$ galactosidase $(\beta-\mathrm{Gal})$, the deficiency of which is associated with generalized gangliosidosis [17]; arylsulfatase A (ARA), the deficiency of which is associated with metachromatic leukodystrophy [1, 12]; and $\beta$-D- $N$-acetylhexosaminidase (Hex), in which the A component is deficient in Tay-Sachs disease [18].

\section{Materials and Methods}

At the time of the surgical procedure a maternal skin biopsy was obtained from the incision site [24]. A 20to $50-\mathrm{ml}$ amniotic fluid sample was obtained either on exposure of the uterus or after its removal. Within 5 min after the fetus was removed, a fetal skin biopsy was performed. After mild centrifugation $(200 \times g)$, for $10 \mathrm{~min}$, amniotic fluid cells were resuspended in culture medium and placed in culture. Fetal and maternal skin samples were minced prior to cultivation. Each cell type was initiated in duplicate culture.

All cell cultures were grown in Eagle's minimal essential medium with Earle salts [25] supplemented with $15 \%$ fetal calf serum [26], $2 \mathrm{~mm}$ L-glutamine, and penicillin/streptomycin $(200 \mathrm{U} / \mathrm{ml}$ and $40 \mu \mathrm{g} / \mathrm{ml}$, respectively). Cultivation was carried out in an atmosphere of $5 \% \mathrm{CO}_{2}$ at $37^{\circ}$. Primary cultures were undisturbed for the first 7-10 days. Subsequently, the medium was changed twice weekly. Monolayer cell growth was successfully achieved in all cultures. Cells were harvested or subcultured after 3-5 min exposure to $0.2 \%$ trypsin 
in $2 \times 10^{-3}$ M EDTA. Mycoplasma screening on representative cultures from each cell line was negative.

All amniotic fluid cell cultures in these studies were either entirely or predominantly fibroblastic in morphology at the time of harvest. No significant differences in the specific activities of the three enzymes studied were found when other amniotic fluid cell cultures with predominantly epithelial morphology were compared with these cells [5].

Because of the practical time limitations as to when transabdominal amniocentesis can be successfully achieved and when therapeutic abortion can be performed, it is usually necessary that amniotic fluid cell cultures be assessed within 6-8 weeks after they have been in culture. As such all amniotic fluid cell cultures were terminated for assay at 6 weeks. Similarly, fetal skin cultures and maternal cells were prepared at the same time. At least two independent cultures of each cell type from each of the seven groups were studied. Each of the three enzymatic assays to be discussed was performed in duplicate on the same culture of each cell type.

Cells at early confluency were trypsinized, collected, washed twice, and sonically disrupted immediately prior to assay. Supernatant fractions were assayed and protein determinations were done by the method of Lowry et al. [11].

All assays were conducted using synthetic aromatic

Table I. Comparative enzymology in fibroblasts cultivated from fetal skin, amniotic fluid cells, and maternal skin

\begin{tabular}{|c|c|c|c|c|c|c|}
\hline \multirow{2}{*}{$\begin{array}{l}\text { Enzyme and } \\
\text { fibroblast } \\
\text { source }\end{array}$} & \multirow{2}{*}{$\begin{array}{l}\text { No. of } \\
\text { lines }\end{array}$} & \multirow{2}{*}{$\begin{array}{l}\text { No. of } \\
\text { determi- } \\
\text { nations }\end{array}$} & \multicolumn{3}{|c|}{ Enzyme specific activity ${ }^{1}$} & \multirow{2}{*}{$P^{3}$} \\
\hline & & & & Mean $^{2}$ & Range & \\
\hline \multicolumn{7}{|l|}{$\beta$-Galactosidase } \\
\hline Fetal skin & 7 & 16 & 248 & \pm 66.5 & $163-424$ & $<0.005$ \\
\hline $\begin{array}{l}\text { Amniotic fluid } \\
\text { cell }\end{array}$ & 7 & 16 & 676 & \pm 339.4 & $298-1440$ & 0.001 \\
\hline $\begin{array}{c}\text { Maternal skin } \\
\beta-\mathrm{D}-N \text {-Acetylglu- } \\
\text { cosamini- } \\
\text { dase }\end{array}$ & 7 & 14 & 375 & \pm 111.6 & $157-598$ & \\
\hline Fetal skin & 7 & 16 & 3412 & \pm 952.0 & $1936-5275$ & $<0.001$ \\
\hline $\begin{array}{l}\text { Amniotic fluid } \\
\text { cell }\end{array}$ & 7 & 16 & 6548 & \pm 2113.0 & $3553-10906$ & $<0.600$ \\
\hline Maternal skin & 7 & 14 & 6781 & \pm 2975.0 & $2466-12795$ & \\
\hline \multicolumn{7}{|l|}{ Arylsulfatase A } \\
\hline Fetal skin & 7 & 16 & 143 & \pm 60.8 & $49-231$ & $<0.001$ \\
\hline $\begin{array}{l}\text { Amniotic fluid } \\
\text { cell }\end{array}$ & $11^{4}$ & 22 & 244 & \pm 69.3 & $107-340$ & $<0.001$ \\
\hline Maternal skin & 7 & 14 & 458 & \pm 126.1 & $225-948$ & \\
\hline
\end{tabular}

1 Expressed in millimicromoles of product produced per hour per milligram of supernatant fibroblast protein. Each determination reflects a duplicate assay on an independent culture of the indicated cell type.

$2 \pm \mathrm{sD}$.

$3 P$ values refer to the significance levels of the difference in mean activity of the fetal and amniotic cells compared with maternal cells.

${ }^{4}$ Includes four unrelated amniotic fluid cell fibroblast lines. substrates [27] which in each case have been shown, using the natural substrate, to reflect the disease-associated enzyme deficiency. The substrates used are $p$-nitrophenyl- $\beta$-D-galactopyranoside for $\beta$-Gal, $p$-nitrocatechol sulfate for ARA, and $p$-nitrophenyl- $N$-acetyl $\beta$-D-glucosaminide for Hex. Cleavage of these aromatic substrates by the appropriate enzyme yields either a nitrophenol or nitrocatechol product which is then quantitated spectrophotometrically.

Initial experiments were conducted to define the optimal conditions for assay for each of these enzymes in pooled samples of cells developed from maternal, fetal, and amniotic fluid cell origin. Linearity with protein concentration, substrate saturation, optimal $\mathrm{pH}$, and linearity with time were established for each assay with each cell type. No significant differences between cell types were found, as to optimal conditions for each assay.

\section{Assay Conditions}

$\beta$-Galactosidase was assayed in a final volume of 0.3 $\mathrm{ml}$ which contained in final concentration: $4.5 \times 10^{-3}$ M $p$-nitrophenyl- $\beta$-D-galactopyranoside; $0.1 \mathrm{M} \mathrm{Na}$ acetate, $\mathrm{pH} 5.0$; and $10-150 \mu \mathrm{g}$ supernatant cell protein. The reaction mixture was incubated for $60 \mathrm{~min}$ at $37^{\circ}$, and the reaction was terminated by the addition of 0.7 $\mathrm{ml} 0.25 \mathrm{~m}$ glycine-carbonate buffer, $\mathrm{pH}$ 10.0. In the reaction blank, the cell protein and substrate were mixed after incubation and the alkaline buffer was added immediately. Optical densities at $420 \mathrm{~m}_{\mu}$ were recorded with a recording spectrophotometer [28].

$\beta$-D- $N$-Acetylglucosaminidase was assayed in a final volume of $0.3 \mathrm{ml}$ which contained in final concentration: $4.0 \times 10^{-3} \mathrm{M} p$-nitrophenyl- $N$-acetyl- $\beta$-D-glucosaminide; $0.1 \mathrm{M}$ citrate-phosphate buffer, $\mathrm{pH} 4.4$; and 10-100 $\mu \mathrm{g}$ supernatant cell protein. Incubation, termination, and optical density measurements were determined in the same manner as those for $\beta$-galactosidase assay.

Arylsulfatase A was assayed as previously described [6].

\section{Results}

Using the conditions defined, the indicated enzymes were assayed in duplicate in the same cells from each of at least two independent cultures of each cell type in each of the seven fetal-amniotic-maternal groups.

Table I shows the accumulated data from these studies. The mean enzyme specific activity, standard deviation, and range of activities for $\beta$-Gal, total Hex, and 
ARA in fetal cells, cultured amniotic fluid cells, and maternal skin fibroblasts are compared. The $P$ values indicated refer to the significance levels of the difference in the mean activity of either the fetal or amniotic cells compared with maternal cells for each enzyme.

Several points are evident. The pattern of enzyme specific activity was different for each of the enzymes studied. $\beta$-Gal activity is highest in the amniotic cell and lowest in the fetal cultures. For Hex, activity of amniotic and maternal cells was not significantly different, but both showed higher levels of activity than did the fetal cells.

The ARA activity in the maternal cells was very significantly greater than that in the cultured amniotic cells, which was, in turn, higher than that found in fetal skin cultures.

For each of these lysosomal enzymes the specific activity of the cultured fetal cells was lower than that found in maternal and amniotic fluid cells. This fact is of considerable interest and is of utmost relevance to corroboration of intrauterine diagnoses. The exact explanation of this difference between the fetal and amniotic cells is not known but may well reflect differential cell aging since lysosomal enzymes may increase as cells age in culture [2].

The variation of enzyme specific activities in each cell type is also shown in Table I. There was a considerable range of activities for each enzyme in all cell types, reflecting, perhaps, the kind of in vitro variation previously mentioned. In each of the seven groups studied, however, the relations between these three enzymes were consistent in the fetal, amniotic, and maternal cells (Fig. 1). The specific activity of each enzyme in the fetal and amniotic cell cultures was plotted as a percentage of the maternal value for comparative purposes. Again the relative activities are different for each enzyme but consistent in all culture groups for the particular enzyme studied.

These differences in enzyme specific activity between cell types could indicate that the enzyme in each cell type was a different molecular species. To assess this possibility, substrate saturation studies were carried out for each enzyme in pooled samples of each of the three cell types. Using the synthetic aromatic substrates previously mentioned, Lineweaver-Burke analysis of enzyme activity as a function of substrate concentration over a 50 -fold range of concentrations indicated no significant difference in the apparent Michaelis-Menten constants for each enzyme in each of the cell types (Table II).

These data, therefore, suggest that the differences in

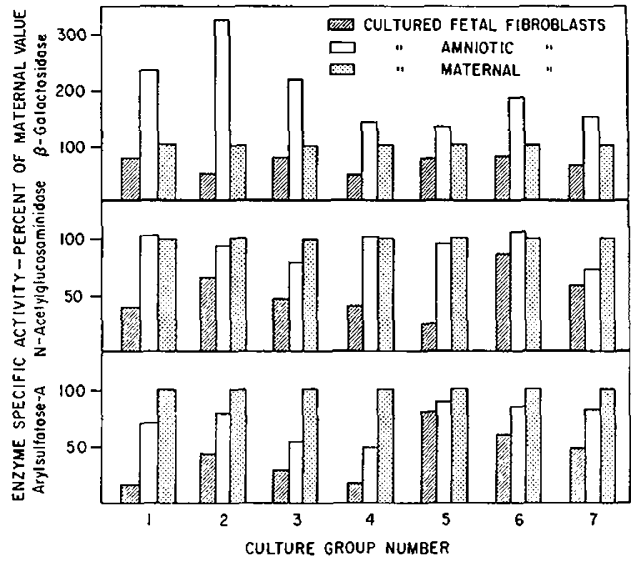

Fig. 1. Relative enzyme specific activities for three lysosomal enzymes in seven fetal-amniotic-maternal cell culture groups. Specific activitics for each enzyme in the fetal and amniotic cells are indicated as a percentage of the maternal value for comparative purposes.

enzyme specific activity were due to inherent differences between the respective cell types under the defined culture conditions.

\section{Discussion}

The relative specific activities between normal amniotic fluid cell cultures and control skin fibroblasts are particularly relevant to intrauterine diagnosis. Activity of $\beta$-galactosidase, as shown here, and cystathionine synthase activity, as shown by Uhlendorf and Mudd [23], are higher in amniotic fluid cells in culture than in normal skin fibroblasts. Arylsulfatase A, as well as argininosuccinase [20], and ornithine keto acid transaminase [21] are lower in specific activity in midtrimester amniotic fluid cell cultures than in control skin fibroblasts.

That the specific activity of different enzymes in amniotic fluid cell cultures may be the same, greater,

Table II. Comparison of apparent Michaelis-Menten constants $\left(K_{m a}\right)$ for three lysosomal enzymes in fibroblasts developed from fetal skin, amniotic fluid cells, and maternal skin ${ }^{1}$

\begin{tabular}{lccc}
\hline \multirow{2}{*}{ Enzyme } & \multicolumn{3}{c}{$K_{m a}, \mathrm{M}$} \\
\cline { 2 - 4 } & Fetal & Amniotic & Maternal \\
\hline$\beta$-Galactosidase & $2.0 \times 10^{-4}$ & $2.1 \times 10^{-4}$ & $2.1 \times 10^{-4}$ \\
$\begin{array}{l}\text { Arylsulfatase A } \\
\beta \text {-D- } N \text {-Acetylglucosamini- } \\
\text { dase }\end{array}$ & $4.2 \times 10^{-3}$ & $2.5 \times 10^{-3}$ & $3.2 \times 10^{-3}$ \\
& $4.8 \times 10^{-4}$ & $5.3 \times 10^{-4}$ & $5.0 \times 10^{-4}$ \\
\hline
\end{tabular}

3 Determined by Lineweaver-Burke analysis of enzyme activity in supernatant fractions from sonicated fibroblasts over a 50 -fold range of substrate concentrations. Substrates used: $p$-nitrophenyl- $\beta$-D-galactopyranoside, 4-nitrocatechol sulfate, $p$-nitrophenyl- $N$-acetyl- $\beta$-D-glucosaminide. 
or most critically lower than in control skin fibroblasts is especially crucial to intrauterine diagnosis [6]. If the specific activity of the disease-related enzyme is lower in control midtrimester amniotic fluid cell cultures, and if heterozygotes for the disease in question fall in a midrange of specific activity between control and affected patients in skin fibroblasts, then one might anticipate that enzyme activity in cultured amniotic fluid cells from a heterozygous fetus would be quite low. As such, differentiation of the heterozygous from the affected fetus based on amniotic cell analysis might be quite difficult for such a disorder. Without first establishing the relative specific activities of both the heterozygote in skin fibroblast culture and the normal cultured midtrimester amniotic fluid cell, compared with control skin fibroblasts, the dilemma might not even be apparent; instead a positive diagnosis indicating an affected fetus might be made incorrectly.

What prerequisite information, therefore, is necessary before the intrauterine diagnostic method can be applied to any given inborn metabolic disease? Primarily the disorder in question must be detectable in an in vitro somatic cell system. Certain conditions like Von Gierke's disease or phenylketonuria, for example, are identifiable only in specific organs of affected patients and not detectable in cell culture, thus ruling out prenatal diagnostic approaches with amniotic fluid cell culture at this time.

Second, the obligate heterozygotes of such a disease must be assessed in that same in vitro system and the relative specific activity of the enzyme or other metabolic variable in question be established between both the carrier-control and carrier-affected populations. For prenatal diagnostic purposes it is certainly not critical that the carrier be distinguishable from the control population. In fact, this situation is preferable since the only real concern for intrauterine diagnosis is to delineate clearly the affected individual from the rest of the population. Failure to differentiate the carrier from the control group is, therefore, of no consequence. It is of utmost importance, however, when carriers fall into a distinct midrange group between normal and affected individuals. This situation is extremely relevant to intrauterine diagnosis as mentioned previously.

A third, and extremely critical requirement, is that the biochemical variable in question be assayed quantitatively in early midtrimester amniotic fluid cultures from normal subjects. Moreover, these control values must be established in cultured cells grown in vitro for less than 8 weeks. This time requirement is essential since therapeutic abortion, in many centers, is only permitted prior to week 22 of pregnancy (based usually on last menstrual period). Because transabdominal amniocentesis usually cannot be performed prior to weeks 14-16 of pregnancy, then test cultures will have to be assessed within 6-8 weeks of amniocentesis. Control amniotic fluid cells which have been in culture for longer periods may have different biochemical-enzymatic properties and, therefore, would not serve as true controls for the test situation.

One cannot assume, because of morphologic and, in some cases, biochemical similarities between cultured amniotic fluid cells and postnatal skin fibroblast cultures, that all biochemical variables will be comparable. Each enzyme or metabolic variable must be individually assessed in each of the pertinent cell types and the appropriate relations established for each.

An additional prerequisite of major importance is that ranges of specific activities be established in normal fetal material at 18-24 weeks gestation. When positive intrauterine diagnoses are made and pregnancies are terminated, corroboration of amniotic fluid cell findings must be made with aborted fetal tissues. Interpretation of these data will be accurate only if normal values at that stage of fetal gestation, in the tissue used for corroboration, are first appreciated. Therapeutic abortions performed for nonorganic indications should provide ample material to establish all these essential control values.

In this regard it must also be ascertained whether or not hypertonic glucose- or saline-aborted fetal material can be used for corroborative studies. Perhaps it will be necessary during this early phase of intrauterine studies, where positive diagnoses of certain diseases are initially being made, that pregnancies be terminated by hysterotomy in order to assess accurately the correctness of the diagnosis.

If in normal fetal tissues used for diagnostic corroboration, enzymatic activity is found to be lower than in normal postnatal cells and control amniotic fluid cells, then again heterozygous fetal material might be extremely low. This might very likely be the case, particularly for those metabolic variables in which normal amniotic cells are lower in activity than control postnatal material and where heterozygotes for the disease in question fall into a distinct midrange group.

Only by establishing these relations first can we avoid the definite possibility of making the wrong diagnosis with amniotic fluid cell analysis and then incorrectly corroborating the error with aborted fetal material.

In summary, then, early midtrimester amniocentesis and amniotic fluid cell analysis would appear to be of 
great value in managing pregnancies at high risk of cytogenetic or sex-linked diseases in the fetus. In addition, several of the inborn metabolic disorders have met the prerequisites discussed above and are also suited to this approach. A number of other biochemical disorders, however, which are potentially detectable by amniotic fluid cell studies have not, as yet, completely met these requirements. It is clear that as such base line data are established, most if not all will be approachable by this method.

\section{Summary}

Highly significant differences were found in the specific activities of $\beta$-galactosidase, arylsulfatase $\mathrm{A}$, and $\beta$-D- $N$ acetylglucosaminidase when these disease-related enzymes were compared in cultured cells from adult skin, fetal skin, and midtrimester amniotic fluid cells. Seven sets of cultures were derived from control pregnancies terminated by hysterotomy or hysterectomy between weeks 17 and 21 of pregnancy. The pattern of enzyme specific activity differed for each enzyme between each of the three cell types: $\beta$-Gal: amniotic $>$ maternal $>$ fetal; ARA: maternal $>$ amniotic $>$ fetal; Hex: maternal $=$ amniotic $>$ fetal.

No significant differences were found in apparent Michaelis-Menten constants for each enzyme in the three cell types studied. The differences in enzyme specific activities are, therefore, most probably due to inherent differences between these cells in culture. The prerequisites needed for accurate intrauterine diagnosis of human genetic-metabolic disorders are discussed in light of these findings.

\section{References and Notes}

1. Austin, J., Armstrong, D., and Shearer, L. Metachromatic form of diffuse cerebral sclerosis. Arch. Neurol., 13: 593 (1965).

2. Cristofalo, V. J., Kabakjian, J. R., and Krirchevsky, D.: Enzyme activities of some cultured human cells. Proc. Soc. Exp. Biol. Med., 126: 273 (1967).

3. Deluca, C., AND Nitowsky, H. M.: Variations in enzyme activities during the growth of mammalian cells in vitro: Lactate and glucose-6-phosphate dehydrogenases. Biochim. Biophys. Acta, 89: 208 (1964).

4. Jacobson, C. B., and BARTER, R. H.: Intrauterine diagnosis and management of genetic defects. Amer. J. Obstet. Gynecol., 99: 796 (1967).

5. KABACK, M. M.: Personal observation.

6. KABACK, M. M., AND HowELL, R. R.: Infantile metachromatic leukodystrophy. Heterozygote detection in skin fibroblasts and possible applications to intrauterine diagnosis. New Engl. J. Med., 282: 1336 (1970).

7. Kaback, M. M., Leonard, C. O., ANd Parmley, T.: Intrauter- ine diagnosis: Comparative enzymology of fibroblasts cultivated from maternal skin, fetal skin, and amniotic fluid cells. Presented in part to The Society for Pediatric Research, Atlantic City, May, 1970 (Abstract, Pediat. Res., in press, 1970).

8. Квоотн, R. S.: Properties of diploid cell strains developed from patients with an inherited abnormality of uridine biosynthesis. Symp. Quant. Biol., 29: 189 (1964).

9. Кrooth, R. S., Darlington, G. A., and Velazquez, A. A.: The genetics of cultured mammalian cells. Annu. Rev. Gen., 2: I4l (1968).

10. Leroy, J. G., and DeMars, R. I.: Mutant enzymatic and cytological phenotypes in cultured human fibroblasts. Science, 157: 804 (1967).

11. Lowry, O. H., Rosebrough, N. J., Farr, A. L., and Randall, R. J.: Protein measurement with the Folin phenol reagent. J. Biol. Chem., 193: 265 (1951).

12. Mehl, E., AND Jatzkewitz, H.: Evidence for the genetic block in metachromatic leukodystrophy (ML). Biochem. Biophys. Res. Commun., 19: 407 (1965).

13. NAdLER, H. L.: Personal communication.

14. NAdLer, H. L.: Prenatal detection of genetic defects. J. Pediat., 74: 132 (1969).

15. Nadler, H. L., ANd Gerbie, A. B.: Role of amniocentesis in the intrauterine detection of genetic disorders. New Engl. J. Med., 282: 596 (1970).

16. O'Brien, J. S., Okada, S., Chen, A., And Fillerup, D. L.: TaySachs disease: Detection of heterozygotes and homozygotes by serum hexosaminidase assay. New Engl. J. Med., 283: 15 (1970).

17. OKADA, S., ANd O'BRIEN, J. S.: Generalized gangliosidosis: Beta-galactosidase deficiency. Science, 160: 1002 (1968).

18. OKada, S., ANd O'Brien, J. S.: Tay-Sachs disease: Generalized absence of a beta- $\mathrm{D}-\mathrm{N}$-acetylhexosaminidase component. Science, 165: 698 (1969).

19. Rirs, P., AND Fuchs, F.: Antenatal determination of foetal sex in prevention of hereditary diseases. Lancet, 2: 180 (1960).

20. Shin, V. E., ANd LlTtrefield, J. W.: Argininosuccinase activity in amniotic-fluid cells. Lancet, 2: 45 (1970).

21. Shih, V. E., and Schulman, J. D.: Ornithine-ketoacid transaminase activity in human skin and amniotic fluid cell culture. Clin. Chim. Acta, 27: 73 (1970).

22. STeEle, M. W., AND Breg, W. R., JR.: Chromosone analysis of human amniotic-fluid cells. Lancet, 1 : 383 (1966).

23. Uhlendorf, B. W., ANd Mudd, S. H.: Cystathionine synthase in tissue culture derived from human skin: Enzyme defect in homocystinuria. Science, 160: 1007 (1968).

24. Informed consent was obtained in accordance with the provisions of the Declaration of Helsinki.

25. Grand Island Biological Company, Chagrin Falls, Ohio.

26. Grand Island Biological Company, Chagrin Falls, Ohio.

27. Sigma Chemical Company, St. Louis, Mo.

28. Model 2000, Gilford Instrument Labs, Oberlin, Ohio.

29. The authors thank Marguerite Sonneborn for excellent technical assistance in these studies.

30. Supported by National Institutes of Health Contract no. 69-79 and by a grant from The National Foundation-March of Dimes.

31. Requests for reprints should be addressed to: Michael $M$. Kaback, M.D., Department of Pediatrics, CMSC 1004, Johns Hopkins Hospital, Baltimore, Md. 21205 (USA).

32. Accepted for publication August 13, 1970. 